\title{
On the Physiological Significance of Metabolite Channelling: If, How, and Where, but not Why
}

Whilst I do not know the constraints on space which Dr Ovádi had to follow, and I do think that she succeeds excellently in a short article in conveying many of the points at issue (not least by making explicit the possibilities encapsulated in her scheme I and table 1), the major criticism of this target review (Ovádi, 1991) that I would make is that it contains a number of inappropriate generalizations.

Reviews of this type, of a broad scope, are naturally prone to excessive generalizations. One which I as a microbiologist have always found a source for concern in the "channelling" field is the use of phrases such as "the cell" (section 6) or "the cytoplasm" (section 3.3), without distinguishing whether this refers to prokaryotic or eukaryotic systems (or both). As is well-known, mitochondria, like the prokaryotes from which they have surely descended (John \& Whatley, 1975), have a much higher protein content (per unit volume) than does the eukaryotic cytoplasm. When discussing the "diffusion of intermediates" problem (section 3.3), therefore, and given the strongly non-linear dependence of diffusion coefficients on "viscosity" (i.e. protein content) (see e.g. Minton, 1990), it is implausible that the same answers will hold true for both prokaryotes and eukaryotes. Whether or not prokaryotes possess cytoskeletal elements, let alone a microtrabecular lattice, of the type found in eukaryotes (see e.g. Clegg, 1984; Porter, 1986), is unknown. The same sorts of arguments apply to membrane processes (Kell, 1984, 1988; Westerhoff et al., 1988), where the prokaryotic(-type) cytoplasmic membrane has three times as much protein per unit lipid than does the eukaryotic type of plasma membrane (Kell \& Westerhoff, 1985), and where the dependence of the diffusion time on the inverse square of the distance (section 3.3) brings a much sharper focus to the problem (Kell, 1984).

With regard to excessive generalizations, one may often find discussion (e.g. Kell, 1979) of the putative advantages to be gained from channelling (including sections 2,5 and 6 ), without stating the boundary conditions. Albeit that this is a truism (if not a teleology), and I am not going to invoke the entire literature on ecology and evolution, most will accept that cells in different environments will be subjected to different selection pressures; the "advantages" of a particular type of metabolism in one environment will not therefore hold in other types of environment (particularly with regard to nutrient supply). Evidently this is a more serious consideration for unicellular organisms (see e.g. Savageau, 1976; Westerhoff et al., 1983), but even apparently inevitable "advantages" (or at least consequences) of metabolite channelling, such as a decreased transient time, may be viewed as disadvantages in a severely fluctuating environment, where some kind of buffering (of metabolic pools) will be of homeostatic benefit. Not least because of the controversial nature of this field, it is probably better for us all to concentrate on how cells are, not why.

"Significant" (section 6.2, paragraph 3) is another weasel word! Since I am not an enzyme kineticist (though I was given to believe that accuracies of $1 \%$ or better 
were achievable in this field), I feel no reason not to say that normally a five-fold difference in an estimation, in this case a $K_{m}$, is considered extremely significant, whether it be a metabolic flux, the concentration of a metabolite in my bloodstream, or my bank balance. Therefore, I think that here Dr Ovádi is too dismissive of the problem. If the effect of channelling becomes immeasurable then it becomes irrelevant, and the whole point of this very nice target review is surely to stress the importance of metabolite channelling. Either the models or the experiments must be improved, and I wonder whether consideration of the putative advantages of channelling might provide more sensitive ways of pointing up its existence, perhaps by looking in more detail at the overall transient time, given the existence of clear-cut relationships between this, the steady-state flux and the total concentration of participating intermediates (Easterby, 1990). Similarly, in systems in which the concentration of an enzyme may be varied independently, the existence of channelling is manifest as a difference in its apparent flux-control coefficient, depending upon whether the concentration of the enzyme is modulated up or down (Kell \& Westerhoff, 1900).

By way of a contrast, one can see under-generalizations in some of Dr Ovádi's remarks. For instance, it is not obvious what special features are possessed by transport systems (section .6.3) that make them different from other enzymes as candidates for metabolite channelling. Indeed, Solomon's work (Fossel \& Solomon, 1976; Solomon, 1978) provides what seem unimpeachable evidence in favour of channelling in the supply of ATP to the erythrocyte $\mathrm{Na}^{+}, \mathrm{K}^{+}$-ATPase.

Finally, I would make two more general comments: first, I think that Dr Ovádi is extremely brave to have provided a manuscript to be used as a "straw man" in this way, given that most points made by the commentators will inevitably be critical rather than laudatory, and secondly that the thought that one's review of or commentary on a paper is to be published does sharpen one's critical faculties to an almost excessive degree.

Department of Biological Sciences, University College of Wales, Aberystwyth, Dyfed SY23 3DA, U.K.

Douglas B. Kell

\section{REFERENCES}

ClegG, J. S. (1984). Am. J. Physiol. 246, R133-R151.

EAsterby, J. S. (1990). In: Control of Metabolic Processes (Cornish-Bowden, A. \& Cárdenas, M. L., eds) pp. 281-290. New York: Plenum Press.

Fossel, E. T. \& Solomon, A. K. (1976). Biochim. Biophys. Acta 464, 82-92.

JOHN, P. \& WhATLEy, F. R. (1975). Nature, Lond. 254, 495-498.

KELL, D. B. (1979). Biochim. Biophys. Acta 549, 55-99.

KELL, D. B. (1984). Trends biochem. Sci. 9,86-88.

KELL, D. B. (1988). In: Bacterial Energy Transduction (Anthony, C. J., ed.) pp. 429-490. London: Academic Press.

KELL, D. B. \& WeSterhoff, H. V. (1985). In: Organized Multienzyme Systems: Catalytic Properties (Welch, G. R., ed.) pp. 63-139. New York: Academic Press.

KELL, D. B. \& WESTERHOFf, H. V. (1990). In: Structural and Organizational Aspects of Metabolic Regulation (Srere, P. A., Jones, M. E. \& Mathews, C. K., eds) pp. 273-289. New York: Wiley.Liss. 
Minton, A. P. (1990). In: Structural and Organizational Aspects of Metabolic Regulation (Srere, P. A., Jones, M. E. \& Mathews, C. K., eds) pp. 291-306. New York: Wiley-Liss.

OVÁDI, J. (1991). J. theor. Biol. 152, 1-22.

PORTER, K. R. (1986). In: The Organization of Cell Metabolism (Welch, G. R. \& Clegg, J. S., eds) pp. 9-25. New York: Plenum Press.

SAVAGeaU, M. A. (1976). Biochemical Systems Analysis, pp. 235-269. Reading, MA: Addison Wesley. Solomon, A. K. (1978). In: Membrane Transport Processes Vol. 1 (Hofmann, J. F., ed.) pp. 31-59. New York: Raven Press.

Westerhoff, H. V., Hellingwerf, K. J. \& VAN Dam, K. (1983). Proc. natn. Acad. Sci. U.S.A.80, 305-309.

WesterhofF, H. V., KeLL, D. B., KAMP, F. \& VAN DAM, K. (1988). In: Microcompartmentation (Jones, D. P., ed.) pp. 115-154. Boca Ratón, FL: CRC Press. 